\title{
Responses of male Greater Prairie-Chickens to wind energy development
}

\author{
Author(s): Virginia L. Winder, Andrew J. Gregory, Lance B. McNew, and Brett K. Sandercock \\ Source: The Condor, 117(2):284-296. \\ Published By: Cooper Ornithological Society \\ DOI: http://dx.doi.org/10.1650/CONDOR-14-98.1 \\ URL: http://www.bioone.org/doi/full/10.1650/CONDOR-14-98.1
}

BioOne (www.bioone.org) is a nonprofit, online aggregation of core research in the biological, ecological, and environmental sciences. BioOne provides a sustainable online platform for over 170 journals and books published by nonprofit societies, associations, museums, institutions, and presses.

Your use of this PDF, the BioOne Web site, and all posted and associated content indicates your acceptance of BioOne's Terms of Use, available at www.bioone.org/page/terms_of_use.

Usage of BioOne content is strictly limited to personal, educational, and non-commercial use. Commercial inquiries or rights and permissions requests should be directed to the individual publisher as copyright holder. 


\title{
Responses of male Greater Prairie-Chickens to wind energy development
}

\author{
Virginia L. Winder, ${ }^{1}$ Andrew J. Gregory, ${ }^{2}$ Lance B. McNew, ${ }^{3}$ and Brett K. Sandercock ${ }^{4 *}$ \\ ${ }^{1}$ Benedictine College, Department of Biology, Atchison, Kansas, USA \\ 2 Bowling Green State University, School of Environment and Society, Bowling Green, Ohio, USA \\ ${ }^{3}$ Montana State University, Department of Animal and Range Sciences, Bozeman, Montana, USA \\ ${ }^{4}$ Kansas State University, Division of Biology, Manhattan, Kansas, USA \\ * Corresponding author: bsanderc@ksu.edu
}

Submitted June 21, 2014; Accepted February 19, 2015; Published May 6, 2015

\begin{abstract}
Renewable energy resources have received increased attention because of impacts of fossil fuels on global climate change. In Kansas, USA, optimal sites for wind energy development often overlap with preferred habitats of the Greater Prairie-Chicken (Tympanuchus cupido), a lek-mating prairie grouse of conservation concern. We tested for potential effects of energy development on male Greater Prairie-Chickens in north-central Kansas. We captured males at 23 leks located 0.04 to $28 \mathrm{~km}$ from wind turbines during a 2-yr preconstruction period (2007-2008) and a 3-yr postconstruction period (2009-2011). First, we tested for effects of proximity to turbines, habitat, and lek size on annual probability of lek persistence and changes in male numbers. We predicted that energy development might result in behavioral avoidance of areas close to turbines, resulting in increased rates of lek abandonment and fewer males attending surviving leks. We found that distance to turbine had a negative effect on lek persistence for leks $<8 \mathrm{~km}$ from turbines during the postconstruction period, supporting the $8-\mathrm{km}$ buffer zone recommended by the U.S. Fish and Wildlife Service as an offset for wind energy projects. Additionally, lek persistence was positively related to number of males counted at a lek and with grassland cover surrounding the lek. Second, we tested for effects of wind energy development on male body mass. We predicted that degraded habitat conditions might result in decreased body mass for males attending leks near turbines during the postconstruction period. Male body mass was $\sim 2 \%$ lower during the postconstruction period, but distance to turbine did not affect body mass. Additional study is needed to determine whether short-term effects of turbines on lek persistence influence population viability of Greater Prairie-Chickens.
\end{abstract}

Keywords: behavioral avoidance, body mass, grouse, lek abandonment, male age, Tympanuchus cupido, wind turbine

\section{Respuestas de los machos de Tympanuchus cupido al desarrollo de energía eólica}

\section{RESUMEN}

Los recursos energéticos renovables han recibido una atención creciente debido a los impactos de los combustibles fósiles en el cambio climático global. En Kansas, los sitios óptimos para el desarrollo de la energía eólica usualmente se superponen con los hábitats preferidos de Tympanuchus cupido, un urogallo de pradera de interés para la conservación que realiza asambleas de cortejo como sistema de apareamiento. Evaluamos los efectos potenciales del desarrollo energético en los pichones machos en el norte centro de Kansas. Capturamos machos en 23 asambleas de cortejo localizadas entre 0.04 y 28 km de las turbinas eólicas durante un período de 2 años previo a la construcción (2007-2008) y un período de 3 años posteriores a la construcción (2009-2011). Primero, evaluamos los efectos de la proximidad a las turbinas, del hábitat y del tamaño de la asamblea de cortejo sobre la probabilidad anual de persistencia de la asamblea de cortejo y los cambios en la cantidad de machos. Predijimos que el desarrollo energético podría traer aparejado un comportamiento de evitar las áreas cercanas a las turbinas, trayendo como resultado un aumento en las tasas de abandono de las asambleas de cortejo y un menor número de machos participando de las asambleas sobrevivientes. Encontramos que la distancia a las turbinas tuvo un efecto negativo en la persistencia de las asambleas de cortejo para asambleas ubicadas a $<8 \mathrm{~km}$ desde las turbinas durante el período posterior a la construcción, apoyando la zona buffer de $8 \mathrm{~km}$ recomendada por el Servicio de Pesca y Vida Silvestre de EEUU como una medida de compensación para los proyectos de energía eólica. Adicionalmente, la persistencia de la asamblea de cortejo estuvo positivamente relacionada al número de machos presentes en una asamblea y a la cobertura de bosque alrededor de la asamblea. Segundo, evaluamos los efectos del desarrollo de la energía eólica en el peso corporal de los machos. Predijimos que las condiciones de los hábitat degradados traerían aparejada una reducción en el peso corporal de los machos presentes en las asambleas de cortejo cercanas a las turbinas durante el período posterior a la construcción. La masa corporal de los machos fue $\sim 2 \%$ menor durante el período posterior a la construcción, pero la distancia a la turbina no afectó el peso corporal. Se necesitan estudios adicionales para determinar si los efectos de corto plazo de las turbinas sobre la persistencia de las asambleas de cortejo influyen en la viabilidad poblacional de T. cupido. 
Palabras clave: abandono de la asamblea de cortejo; comportamiento de elusión; edad del macho; peso corporal; turbina eólica; Tympanuchus cupido; urogallo

\section{INTRODUCTION}

Environmental and social concerns regarding U.S. reliance on fossil fuels have led to changes in energy policy, including support for renewable resources (U.S. Department of Energy 2008). In 2008, the U.S. Department of Energy set a benchmark that 20\% of U.S. energy demand should be met by domestic wind energy by 2030 (U.S. Department of Energy 2008, Obermeyer et al. 2011). However, renewable energy development presents potential conflicts with conservation of sensitive species of wildlife (Drewitt and Langston 2006, Kuvlesky et al. 2007, Smallwood and Thelander 2008, Obermeyer et al. 2011, Pearce-Higgins et al. 2012). Migratory birds and bats are at risk of population-level impacts associated with broad-scale wind energy development (Kunz et al. 2007). The extent to which mortality related to energy infrastructure is compensatory or additive to natural mortality remains unknown for most wildlife species (Schaub and Lebreton 2004, Arnold and Zink 2011, Sandercock et al. 2011).

Direct effects of wind energy development can include collision mortalities, but indirect effects of behavioral avoidance or displacement have also been documented in animal populations (Doherty et al. 2008, Sovacool 2009, Johnson and Stephens 2011, Blickley et al. 2012a, 2012b, Winder et al. 2014b; but see Hale et al. 2014). Anthropogenic disturbance may also induce physiological stress responses among animals in landscapes with energy development, reducing body condition or survival (Lima 1986, Mainguy et al. 2002, Blickley et al. 2012a, 2012b). Lesser Prairie-Chickens (Tympanuchus pallidicinctus) avoid nesting near vertical structures and crossing transmission lines and roads (Pitman et al. 2005, Pruett et al. 2009, Hagen et al. 2011). Similarly, Greater SageGrouse (Centrocercus urophasianus) are negatively affected by proximity to oil and gas extraction wells, roads, towers, and transmission lines, resulting in abandonment of leks, avoidance of anthropogenic structures, loss of nesting habitat, reduced survival, and failed recruitment (Walker et al. 2007, Doherty et al. 2010, Harju et al. 2010, Blickley et al. 2012a, Hess and Beck 2012, Dinkins et al. 2014, Gregory and Beck 2014).

Prairie grouse (Tympanuchus spp.) may be particularly sensitive to wind energy development because they have large home ranges, specialized habitat requirements, and use leks for communal display sites (Connelly et al. 2000, Svedarsky et al. 2000, Augustine and Sandercock 2011, Hess and Beck 2012, Winder et al. 2014b). All prairie grouse have a lek-mating system, with males competing for mating opportunities in groups of 10-20 birds (Höglund and Alatalo 1995, Gibson 1996a, 1996b, Nooker and Sandercock 2008, Johnson et al. 2011). Males select open grassland areas on hilltops for lek sites, maximizing visibility and auditory detection by females (Niemuth 2003, Aspbury and Gibson 2004, Gregory et al. 2011). Female prairie grouse visit leks to select a mate, nest within 1-5 km of lek sites, and provide all parental care of young (Schroeder and White 1993, Winder et al. 2014b). Optimal locations for wind turbines are also open, exposed grassland sites at relatively high elevations. Turbines erected on ridgelines or hilltops ensure the efficiency of wind use and avoid valuable cropland (Drewitt and Langston 2006), but coincide with preferred lekking sites for prairie grouse, increasing the potential for windwildlife conflicts.

The aim of our study was to investigate the potential effects of wind energy development on male Greater Prairie-Chickens (Tympanuchus cupido). In previous work, we reported that female Greater Prairie-Chickens avoid wind turbines in their space use and movements, but turbines do not negatively affect nest-site selection, nest survival, or adult survival (McNew et al. 2014, Winder et al. 2014a, 2014b). Here, we use a before-after control-impact (BACI) design to test for effects of energy development on lek dynamics and body mass of male Greater Prairie-Chickens before and after construction of a wind energy facility (Figure 1). First, the presence of turbines might negatively affect lek dynamics if males avoid tall structures or if construction activity leads to physical disturbance at lek sites (Blickley et al. 2012a, Hess and Beck 2012). We tested for the effects of wind energy development on lek persistence and rate of change in number of males at active leks at 2 spatial scales: (1) the study area as a whole $(0-28 \mathrm{~km}$ from turbines) and (2) the zone of greatest expected impact $(<8 \mathrm{~km}$ from turbines; Manville 2004). If wind energy development has negative impacts, we predicted increased rates of lek abandonment and negative rates of change in the number of males at active leks near turbines. Second, an animal's body mass may be a measure of its energetic state, and empirical studies often report that individual body mass is correlated with survival, reproductive output, and mate choice (Bachman and Widemo 1999, Mainguy et al. 2002). Reduced body mass in males could alter the dynamics of male-male competition and affect patterns of male reproductive success. If energy development negatively affects male quality, we predicted that male body mass would decrease as a result of physiological stress induced by 


\section{Legend}

- Lek

- Wind turbine

$\bowtie$ Substation

-------- Transmission Line Pre

-.........-- Transmission Line Post

\section{County road}

State highway
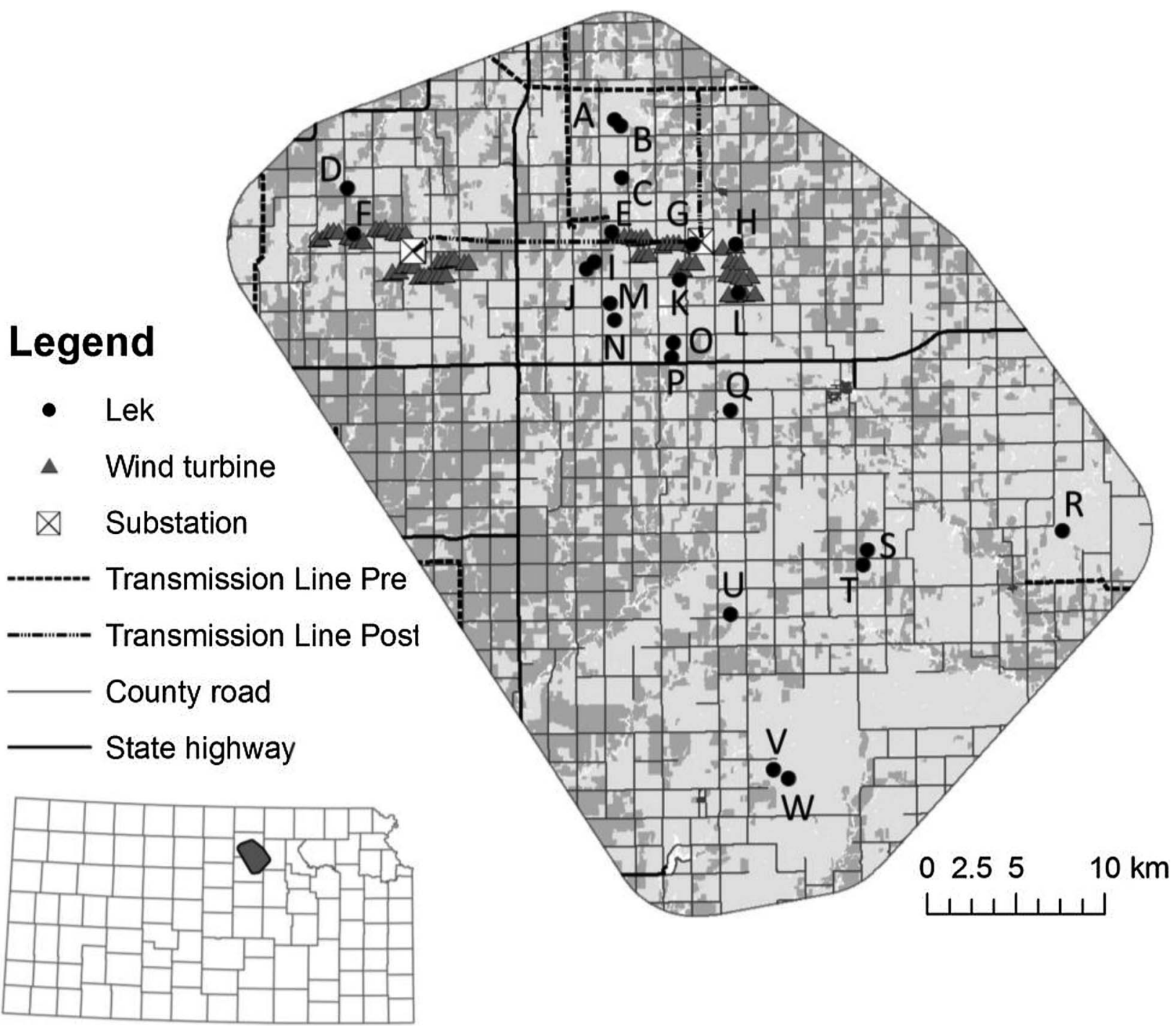

FIGURE 1. Map of the study area in north-central Kansas, USA, 2007-2011. Light gray shading indicates native grasslands managed for cattle grazing; dark gray shading indicates row-crop agriculture. Thick black lines are state highways; thin gray lines are county roads. Study area boundaries were defined by a 5-km buffer around nest sites of radio-tagged females. Letters next to lek symbols correspond to lek designations in Appendix Table 2.

anthropogenic disturbance following energy development (Blickley et al. 2012b).

A critical test for negative effects of wind energy development is to compare demographic responses as a function of distance to turbine, treatment period, and the interaction of these 2 factors. If energy development has a negative effect, we predicted that the interaction term should be significant. We expected no relationship between distance to turbine and probability of lek persistence, rate of change in number of males attending leks, or male body mass during the preconstruction period. However, during the postconstruction period, we expected positive relationships between Greater Prairie-Chicken responses and proximity to disturbance.

\section{METHODS}

\section{Study Site}

Our $\sim 1,300-\mathrm{km}^{2}$ study site was located $\sim 13 \mathrm{~km}$ south of Concordia in the Smoky Hills ecoregion of north-central Kansas, USA (Figure 1). Land cover was mainly native grasslands or pasture (58\%) or row-crop agriculture (35\%), with some restored grasslands in the Conservation Reserve Program (5\%) and some small woodlots (2\%). The landscape was fragmented with a road density of $1.4 \mathrm{~km}$ of road $\mathrm{km}^{-2}$. Native grasslands were managed for cattle production (0.25-0.5 cattle $\mathrm{ha}^{-1}$ for 90 days from late April through late July) with 1 prescribed spring burn every 3 yr. Weather conditions were similar among years and between 
treatment periods during our 5-yr study period, 20072011 (Winder et al. 2014a: fig. S1).

Horizon Wind Energy started construction of the Meridian Way Wind Power Facility in April 2008 and began commercial operation in December 2008. The completed facility comprised 67 Vestas V90 3.0 MW turbines and had a total installed capacity of $201 \mathrm{MW}$. Turbine towers were $\sim 90 \mathrm{~m}$ tall, and rotating blades were $\sim 45 \mathrm{~m}$ in length. Mean ( $\pm \mathrm{SE}$ ) distance between turbines was $328 \pm 12 \mathrm{~m}$ (median $=298 \mathrm{~m}$; range: $257-763 \mathrm{~m}$ ). Major transmission lines were buried underground within the wind energy facility, but a new high-capacity transmission line was built to connect the new power substations to the infrastructure of existing transmission lines $(\sim 25 \mathrm{~km}$; Figure 1). We included 2008 in the preconstruction treatment period because road building and erection of turbines occurred 3-6 mo after the Greater Prairie-Chicken's breeding season was completed. Construction of the facility did not follow U.S. Fish and Wildlife Service recommendations with respect to placement of wind turbine sites (Manville 2004). Potential for impacts was high because a majority of leks $(74 \%, 17$ of 23$)$ were located $<8 \mathrm{~km}$ from the nearest turbine. No mitigation or changes in rangeland management were implemented during the postconstruction period.

\section{Capture and Monitoring}

We monitored Greater Prairie-Chickens at our study site for a 2-yr preconstruction period (2007-2008) and a 3-yr postconstruction period (2009-2011). We located leks with the assistance of landowners and wildlife conservation officers and also searched for displaying Greater PrairieChickens during March-April at sunrise on calm days with low winds. We systematically visited each lek multiple times (range: $1-37$ visits; median $=9$ visits) during each lekking season (March-May) and counted the number of birds at each lek. During a flush count, we visited a lek within the 3-hr period after sunrise and counted all birds flushed from the lek site. It was not possible to distinguish between males and females during flush counts. During a trap count, we deployed sets of walk-in traps or drop-nets and observed lekking activities from blinds. We used scan sampling to tally the maximum numbers of males and females observed during an observation period within $\sim 3$ $\mathrm{hr}$ of sunrise (including trapped and untrapped birds; Nooker and Sandercock 2008). All trapping sessions occurred at sunrise to minimize the risk of captured birds overheating during handling. Males and females were distinguished by plumage and behavioral postures. At first capture, we marked all birds with a uniquely numbered metal leg band and 3 colored leg bands, and sexed and aged birds by plumage. We identified second-year (SY) birds by their retention of the outer 2 primaries with pointed tips from the juvenal plumage, whereas after- second-year (ASY) birds had rounded feather tips on the outer 2 primaries (Henderson et al. 1967).

\section{Data Analysis}

Lek dynamics. All statistical analyses were performed using $\mathrm{R}$ version 2.15.1 (R Foundation for Statistical Computing, Vienna, Austria). We collected lek survey data using 2 techniques. We started by comparing counts from flush counts and trap counts for leks surveyed with both techniques in the same year. The maximum number of males observed during trap counts at leks averaged $90 \% \pm$ $3 \%(n=72)$ of the maximum count of birds observed during flush counts at leks. To combine data from the 2 sampling techniques, we discounted maximum flush counts by $10 \%$ and calculated weighted means, where the maximum count from both flush and trap counts was weighted by the number of visits that counted birds with each technique. We then used the weighted mean as the maximum number of males recorded at each lek per year (Garton et al. 2011). We tested for the effects of wind energy development on 2 aspects of lek dynamics: probability of lek persistence and rate of change in the number of males attending active leks $(r)$. For both aspects of lek dynamics, we tested for effects at 2 spatial scales: the study site as a whole $(0-28 \mathrm{~km}$ from wind turbines) for both preconstruction and postconstruction periods, and the zone of greatest impacts predicted by U.S. Fish and Wildlife (USFWS) siting guidelines during the postconstruction period ( $<8 \mathrm{~km}$ from turbines; Manville 2004).

We used eventual turbine sites for the preconstruction period, and actual turbine locations during the postconstruction period. Distance to eventual turbine sites during the preconstruction period provided a good baseline that controlled for possible gradients in habitat conditions in a heterogeneous landscape. Distance to the nearest turbine was highly correlated with distance to access roads, aboveground transmission lines, and other wind energy features $(r \geq 0.8, P<0.001)$. Therefore, we used distance to nearest turbine as an index of anthropogenic disturbance and associated infrastructure of energy development.

We modeled the annual probability of lek persistence with logistic regression and considered a lek "active" if the maximum count was $\geq 4$ males during a season or "inactive" if all counts were $<4$ males. In our study area, groups of 1-3 males were usually transient or satellite leks that did not persist within a breeding season. We calculated lek persistence as the transitional probability of a lek remaining active from one breeding season to the next. Some leks were as close as $0.5 \mathrm{~km}$ to a neighboring lek (Figure 1), but we treated adjacent leks as independent because only $2 \%$ of recaptured males were captured at multiple leks in a single year (see below). Strong lek fidelity among males is common in lek-mating grouse (Drummer 
et al. 2011, Gibson et al. 2014), but annual turnover of males at leks is typically $>50 \%$ (Nooker and Sandercock 2008). Thus, we treated observations of the same lek across multiple annual intervals as independent observations and used lek-years as the sample unit in our analysis. We monitored 1 interval before development of the wind energy facility (2007-2008), and 3 intervals during the postconstruction period $(2008-2009,2009-2010,2010$ 2011). We modeled the annual probability of lek persistence as a function of 4 factors: treatment period (preconstruction vs. postconstruction), distance to nearest turbine, maximum count of males at a lek before each interval, and lek habitat (leks existing in grassland vs. agricultural fields).

We evaluated trends in lek attendance using the rate of change in the number of male birds attending active leks. We calculated the annual rate of change among males as the natural $\log$ of the ratio of maximum counts of males at a lek in 2 consecutive years: $r=\ln \left(N_{t+1} / N_{t}\right)$ (Garton et al. 2011). We modeled the rate of change in male numbers as a function of distance to nearest turbine and lek size for both preconstruction and postconstruction periods with generalized additive models in package " $\mathrm{mgcv}$ " in $\mathrm{R}$ (Wood 2011).

Effects on male body mass. We restricted our analysis of body mass to males because seasonal dynamics of female body mass included large increases when females were gravid with eggs, followed by loss of body mass during incubation (B. K. Sandercock personal observation). A few birds were not aged at capture $(<10 \%)$, and we restricted our analyses to males of known age (SY vs. ASY). First, we calculated coefficients of variation (CV) for 4 morphometric measures that are often related to body size: lengths of wing, tarsus, head, and tail. We then used Spearman's correlations to test for associations between male body size and body mass in the package "crs" in $\mathrm{R}$ (Racine and Nie 2012). The CVs were low for all 4 morphometric measures (3-8\%), and correlations revealed little or no association between body mass and any linear measurement of body size $(r=0.01-0.17)$. Accordingly, we used unadjusted body mass instead of size-corrected mass in our analysis (Peig and Green 2009). We used linear models to test for interactive effects of treatment (preconstruction vs. postconstruction) and age-class (SY vs. ASY) on male body mass. We used generalized additive models to test for effects of distance to turbine and date of capture on male body mass for each treatment period and age-class.

\section{RESULTS}

\section{Lek Dynamics}

We monitored 23 lek sites during our 5-yr study. Most lek sites were in native grasslands $(n=14)$, but birds also formed leks in agricultural fields, including corn stubble and early winter wheat $(n=9)$. The median peak count per lek was 13 males (range: $4-32, n=75$ lek-years), but counts of males per lek changed from year to year (Appendix Table 2). The median distance from the lek site to the eventual or actual site of the nearest turbine was $3.9 \mathrm{~km}$ (range: $0.04-27.6 \mathrm{~km}$ ). We recorded 635 capture records for 408 males, with 156 males captured more than once. Males showed strong site fidelity to lek sites; $94.2 \%$ of recaptured males were recaptured at the same lek where they were initially marked. Few males switched leks within years $(1.9 \%, 3$ of 156$)$ or between years $(3.8 \%, 6$ of 156). Males captured at different leks moved from 0.5 to $8.1 \mathrm{~km}$ (mean $\pm \mathrm{SD}=2.7 \pm 2.7 \mathrm{~km}, n=9$ ). Because few males switched leks within a year, we treated all leks as independent display sites.

We observed an increased rate of lek abandonment near turbines within the subset of leks that were $<8 \mathrm{~km}$ from turbines during the postconstruction period (2009-2011; odds ratio $=1.84, z=2.36, \mathrm{df}=35, P=0.02$; Figure $2 \mathrm{~A}$ ). The probability of lek persistence was $\sim 0.5$ for leks $<1 \mathrm{~km}$ from a turbine, $\sim 0.9$ for leks $3 \mathrm{~km}$ from a turbine, and $>0.95$ for leks $\geq 6 \mathrm{~km}$ from a turbine. During the postconstruction period, the rate of abandonment for leks $<8 \mathrm{~km}$ from a turbine tended to be $3 \times$ higher $(22 \%, 8$ of 37 lek-years) compared to leks $\geq 8 \mathrm{~km}$ from turbine ( $8 \%, 1$ of 12 lek-years; odds ratio $=3.0,95 \%$ CI: $0.3-72.3$ ).

Across the study area as a whole, the probability of lek persistence did not differ between the preconstruction period (1 interval) and the postconstruction period (3 intervals, $P=0.62$; Table 1 ). Similarly, the probability of lek persistence was not related to the distance to the nearest turbine in an additive model $(P=0.14$; Table 1 and Figure $3 \mathrm{~A}, 3 \mathrm{~B}$ ) or in a factorial model that included the effects of treatment and distance to turbine as an interaction term $(\mathrm{df}=59, z=1.61, P=0.11)$. However, we observed a nonsignificant trend for increasing levels of lek abandonment for leks near turbines. The probability of lek persistence was $\geq 0.8$, regardless of distance to eventual turbine sites during the preconstruction period (Figure $3 \mathrm{~A})$. During the postconstruction period, the probability of lek persistence ranged from 0.66 at $0.04 \mathrm{~km}$ to 0.99 at 28 $\mathrm{km}$ from actual turbine sites (Figure $3 \mathrm{~B}$ ).

Two additional explanatory factors affected the probability of lek persistence: lek size and habitat type (Table 1). The maximum count of males observed at a lek at the start of an interval had a strong effect on the probability of lek persistence (odds ratio $=1.59, z=2.79, \mathrm{df}=59, P=0.005$ ). The probability of lek persistence was $\sim 0.3$ for leks of 5 males, $\sim 0.5$ for leks of 7 males, and $>0.9$ for leks of $\geq 11$ males during the postconstruction period (Figure 4B). Leks in agricultural fields were abandoned in 6 of 24 (25\%) lekyears, whereas leks in grassland habitats were abandoned in 4 of $36(11 \%)$ lek-years. Leks located in grasslands had 


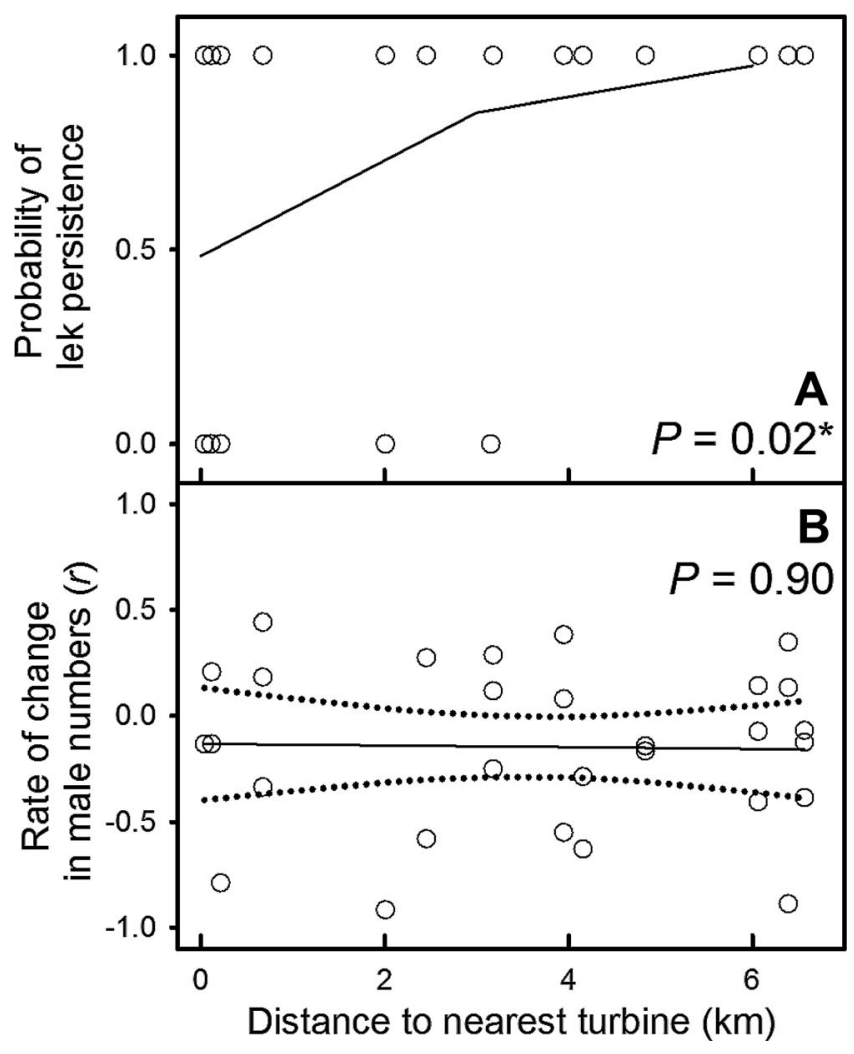

FIGURE 2. (A) Probability of lek persistence: $0=$ inactive $(0-3$ males); 1 = active ( $\geq 4$ males). (B) Rate of change in male numbers at active leks as a function of distance to nearest wind turbine. Analyses were limited to Greater Prairie-Chicken leks within $8 \mathrm{~km}$ of wind turbines after the construction of a wind energy development site in north-central Kansas, USA (20082011). Solid line = predicted line of best fit from (A) a maineffects logistic regression model or (B) a generalized additive model for distance to turbine (dotted lines $=95 \%$ confidence limits).

greater odds of persistence than leks located in agricultural fields (odds ratio $=18.6, z=2.29, \mathrm{df}=59, P=0.02$ ).

We found no detectable effect of distance to turbine on the rate of change in number of males at active leks close to turbines $(<8 \mathrm{~km})$ during the postconstruction period
$\left(F_{1,29}=0.02, P=0.90\right.$; Figure $\left.2 \mathrm{~B}\right)$. Active leks were stable at all distances $(r \approx 0)$. Similarly, distance to turbine had no effect on the rate of change across the entire study area $(0-$ $28 \mathrm{~km})$ during either the preconstruction period $\left(F_{1,9}=\right.$ $0.11, P=0.75$; Figure $3 \mathrm{C}$ ) or the postconstruction period $\left(F_{1,41}=0.71, P=0.40\right.$; Figure $\left.3 \mathrm{D}\right)$. Moreover, lek size had no effect on the rate of change during the preconstruction period $\left(F_{1,9}=1.25, P=0.31\right.$; Figure $\left.3 \mathrm{E}\right)$ or the postconstruction period $\left(F_{1,41}=0.23, P=0.14\right.$; Figure $3 F)$. We observed a negative but nonsignificant trend for a decreased rate of change among larger leks during both treatment periods (Figure 4C, 4D). In both treatment periods, the rate of change was greater for leks of 6 males versus 13 males $(r=0.24$ vs. $r=0.03$ during preconstruction; $r=0.03$ vs. $r=-0.08$ during postconstruction) and for leks of 13 males versus 21 males $(r=0.03$ vs. $r=-0.09$ during preconstruction; $r=-0.08$ vs. $r=-0.79$ during postconstruction; Figure 4C, 4D).

\section{Body Mass}

Body mass of males was $\leq 2.4 \%$ higher during the preconstruction period (SY: $\bar{x}=1.041 \pm 0.081 \mathrm{~kg}$, range: $0.930-1.180 \mathrm{~kg}, n=52$; ASY: $\bar{x}=1.052 \pm 0.084 \mathrm{~kg}$, range: $0.810-1.220 \mathrm{~kg}, n=63)$ compared to the postconstruction period (SY: $\bar{x}=1.017 \pm 0.052 \mathrm{~kg}$, range: $0.910-1.180 \mathrm{~kg}, n$ $=102$; ASY: $\bar{x}=1.031 \pm 0.069 \mathrm{~kg}$, range: $0.910-1.180 \mathrm{~kg}, n$ $\left.=69 ; F_{3,282}=4.89, P=0.049\right)$. Male body mass was not affected by age-class $\left(F_{3,282}=4.89, t=-1.51, P=0.13\right)$ or by an interaction between treatment period and age-class $\left(F_{3,282}=4.89, t=0.28, P=0.78\right)$. Distance to turbine had no detectable effect on male body mass for either age-class or treatment period $(F=0.01-3.44, \mathrm{df}=1$ and $51-101, P=$ 0.07-0.95; Figure 5). Date of capture affected body mass of SY males during both the preconstruction period $\left(F_{1,51}=\right.$ 4.07, $P=0.004$; Figure $6 \mathrm{~A}$ ) and the postconstruction period $\left(F_{1,101}=6.95, P=0.0002\right.$; Figure $\left.6 \mathrm{~B}\right)$. Date of capture was not a significant predictor of body mass for ASY males; but, similar to the result in SY males, body mass tended to be lower for ASY males captured at the end of the lekking season $(P>0.08$; Figure $6 \mathrm{C}, 6 \mathrm{D})$.

TABLE 1. Logistic regression model for annual probability of lek persistence in Greater Prairie-Chickens in the Smoky Hills ecoregion of north-central Kansas, USA, 2007-2011.

\begin{tabular}{|c|c|c|c|c|}
\hline Main effect $^{a}$ & Estimate & SE & $z$ & $P$ \\
\hline Intercept & -5.42 & 2.05 & -2.65 & 0.008 \\
\hline Treatment ${ }^{b}$ & 0.65 & 1.31 & 0.50 & 0.619 \\
\hline Distance to turbine & 0.13 & 0.08 & 1.48 & 0.139 \\
\hline Habitat ${ }^{c}$ & 2.92 & 1.27 & 2.29 & 0.022 \\
\hline Number of males ${ }^{d}$ & 0.47 & 0.17 & 2.79 & 0.005 \\
\hline
\end{tabular}

${ }^{\text {a }}$ Model: lek persistence $\sim$ treatment + distance to turbine + habitat + number of males; $\mathrm{df}=59$.

${ }^{\mathrm{b}}$ Treatment $=$ preconstruction (baseline) vs. postconstruction period.

${ }^{c}$ Habitat $=$ lek located in grassland (baseline) or cropland.

${ }^{\mathrm{d}}$ Number of males $=$ maximum single-day count of males attending the lek at the start of the interval. 


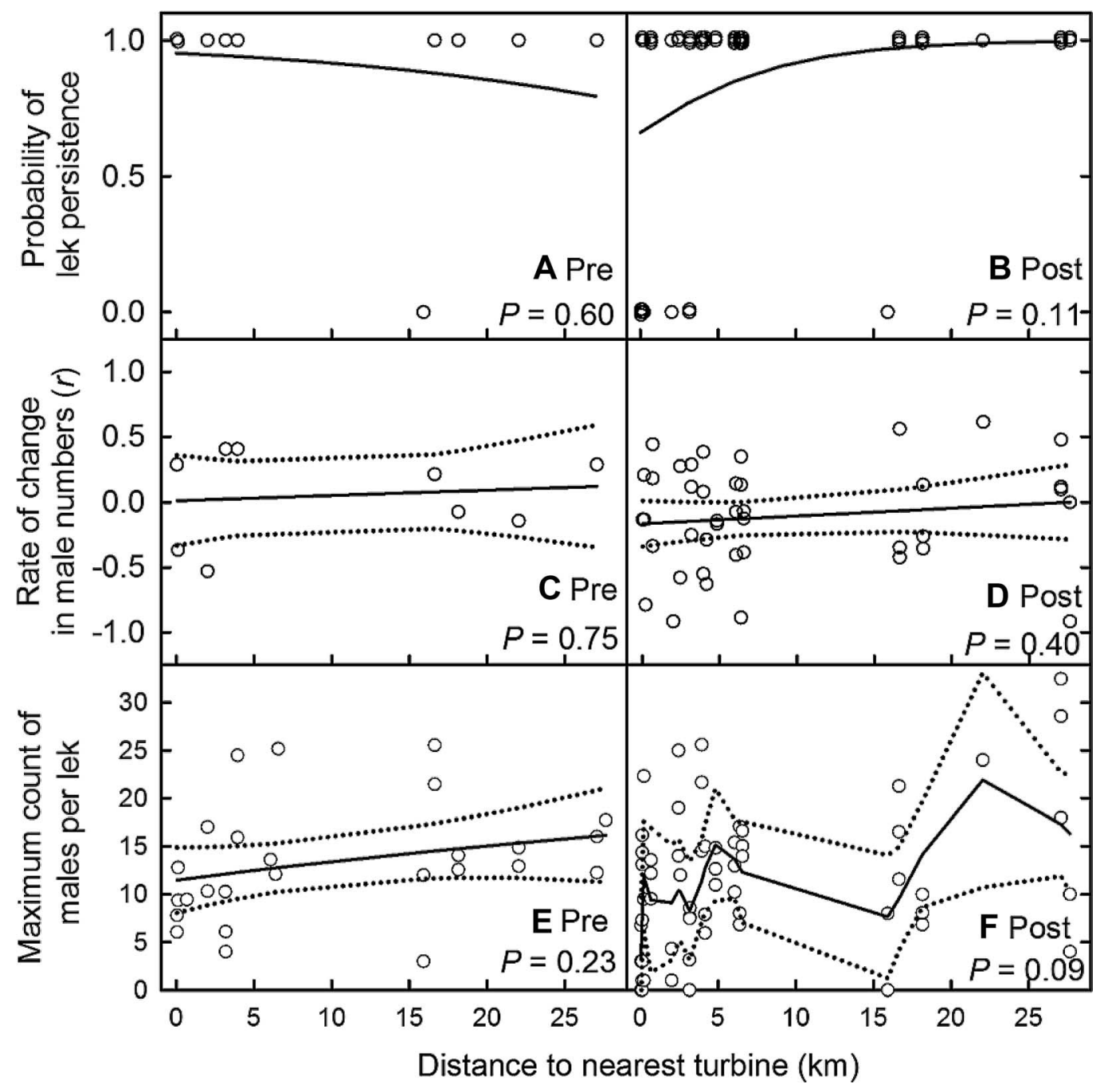

FIGURE 3. (A, B) Probability of lek persistence: $0=$ inactive ( $0-3$ males); 1 =active ( $\geq 4$ males). (C, D) Rate of change in male numbers at active leks. (E, F) Maximum count of males per lek as a function of distance to nearest wind turbine for leks $<30 \mathrm{~km}$ from turbines. We monitored Greater Prairie-Chicken leks at a wind energy development site in north-central Kansas, USA, during 2 treatment periods: (A, C, E) preconstruction (2007-2008) and (B, D, F) postconstruction (2008-2011). Solid line = predicted line of best fit from (A, B) a main-effects logistic regression model or $(\mathbf{C}-\mathbf{F})$ a generalized additive model for distance to turbine for each treatment period (dotted lines $=95 \%$ confidence limits). Points are jittered for clarity in $\mathbf{A}$ and $\mathbf{B}$.

\section{DISCUSSION}

\section{Lek Dynamics}

Changes in lek location and male numbers are natural features of population dynamics in lekking grouse (Bradbury et al. 1989, Schroeder and Braun 1992, Gibson 1996b, Johnson et al. 2011, Geary et al. 2012). Recent studies of Greater Sage-Grouse have linked reductions in lek attendance and persistence to anthropogenic structures associated with energy development (Lyon and Anderson 2003, Doherty et al. 2010, Harju et al. 2010, Hess and Beck 2012, Gregory and Beck 2014). Our study investigated the responses of male Greater Prairie-
Chickens to wind energy development in a landscape dominated by native prairie in north-central Kansas. Our ability to detect potential impacts was high because (1) our BACI study design provided a strong experimental framework, (2) $\sim 50 \%$ of leks in our study were $<4 \mathrm{~km}$ from a turbine, and (3) $\sim 75 \%$ of leks were within the 8 $\mathrm{km}$ buffer zone recommended as an offset for siting of turbines during energy development (Manville 2004, Allison et al. 2010).

We found evidence for negative effects of wind energy development on the persistence of Greater Prairie-Chicken leks $<8 \mathrm{~km}$ from turbines. Lek abandonment was twice as likely for leks $<1 \mathrm{~km}$ from a turbine, compared to leks 3-8 


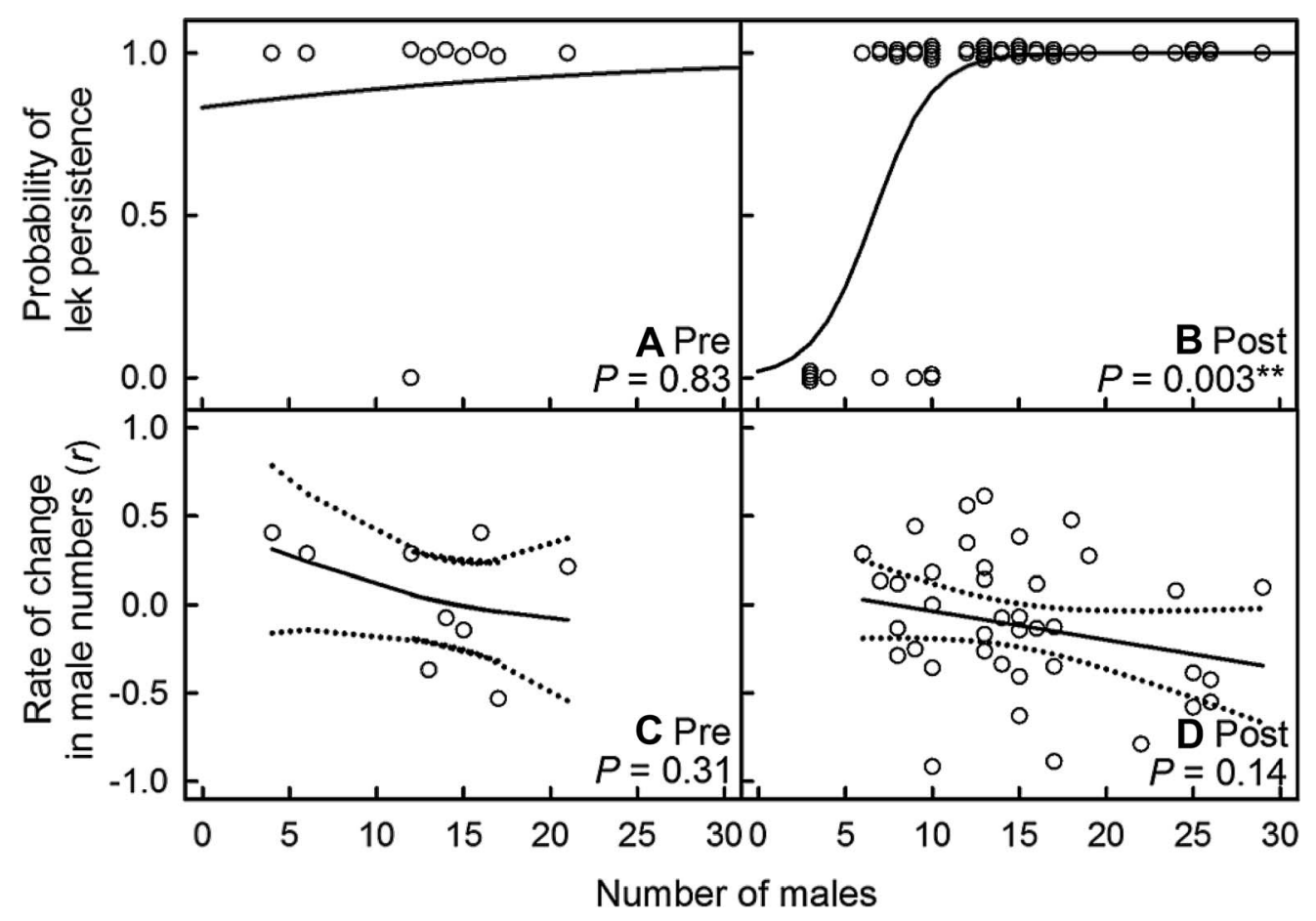

FIGURE 4. (A, B) Probability of lek persistence: $0=$ inactive ( $0-3$ males); $1=$ active ( $\geq 4$ males). (C, D) Rate of change in male numbers at active leks as a function of number of attending males. We monitored Greater Prairie-Chicken leks at a wind energy development site in north-central Kansas, USA, during 2 treatment periods: (A, C) preconstruction (2007-2008) and (B, D) postconstruction (20082011). Solid line = predicted line of best fit from (A, B) logistic regression model or (C, D) generalized additive model for number of attending males for each treatment period (dotted lines $=95 \%$ confidence limits). Points are jittered for clarity in $\mathbf{A}$ and $\mathbf{B}$.

$\mathrm{km}$ from turbines during the postconstruction period. The negative impact of wind energy development approached an all-or-nothing response. For $75 \%$ of the leks that became inactive $<8 \mathrm{~km}$ from a turbine during the postconstruction period, maximum counts of males dropped either to zero males (4 of 8 leks) or to a single male ( 2 of 8 leks). However, for leks that remained active $(\geq 4$ males) during the postconstruction period, distance to turbine had no detectable effect on rates of change $(r \approx 0)$.

We identified 2 additional factors that had a strong effect on lek persistence across our study site as a whole: lek size at the start of an interval and the habitat surrounding a lek. Leks had an increased risk of abandonment when poor recruitment or low survival of males reduced group size to $\leq 7$ males and where leks were located in agricultural fields. Our results are consistent with those of Merrill et al. (1999), who found that stable leks of Greater Prairie-Chickens were surrounded by larger patches of grassland and that temporary leks were associated with forest and cropland in northern Minnesota.

Schroeder and Braun (1992) proposed that environmental changes that affect nesting habitat are an explanation for variable lek stability in Greater PrairieChickens. Female Greater Prairie-Chickens avoid disturbed areas and major roads while selecting for high levels of vegetative cover for nests, and females' space use is tightly linked to the distribution of lek sites (McNew et al. 2013, 2014, Winder et al. 2014b). By contrast, female Greater Sage-Grouse select nest sites independently of lek locations, and males adjust lek locations and attendance rates to maximize contact with females, consistent with the "hotspot hypothesis" for lek evolution (Bradbury et al. 1989, Gibson 1996a). We observed decreased rates of lek persistence for leks located in agricultural fields, which are habitats avoided by females when selecting nest sites (McNew et al. 2014). This provides indirect evidence for the hypothesis that lek persistence is linked to female habitat preferences for large tracts of grassland (Schroeder and Braun 1992, Winder et al. 2014b). Thus, annual lek surveys can be an effective tool for monitoring prairie grouse populations, and counts of males at a lek may indicate the quality of nesting habitat surrounding a lek.

\section{Body Mass}

We observed a small decrease in body mass of males during the postconstruction period that was unrelated to distance to turbine $(<2.5 \%)$. Reduced residual body mass has been correlated with reduced reproductive potential and survival in several bird species (Lindén et al. 1992, Bachman and Widemo 1999, Mainguy et al. 2002). 


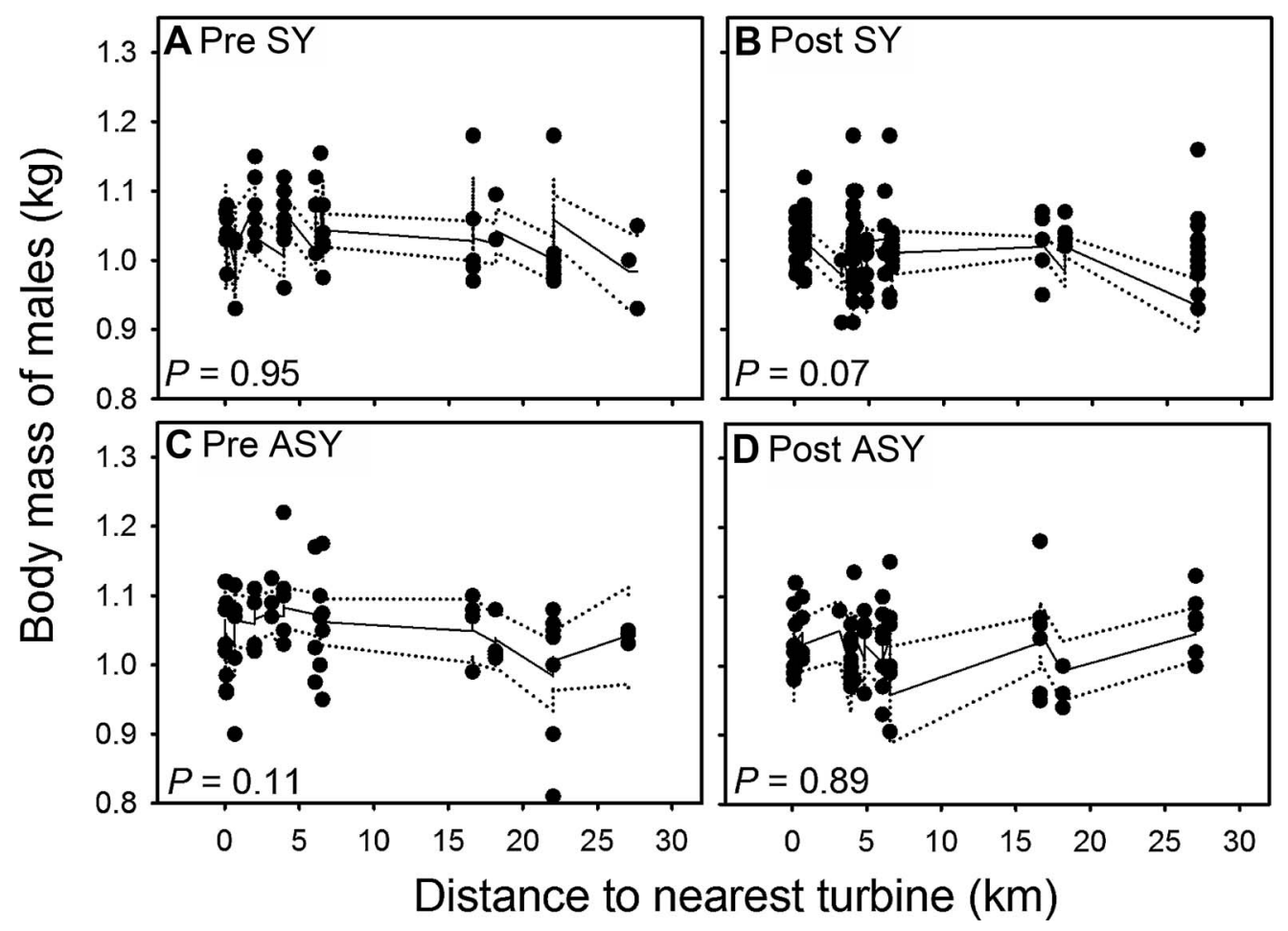

FIGURE 5. Generalized additive model for the effects of distance to turbine on body mass of male Greater Prairie-Chickens at a wind energy development site in north-central Kansas, USA: (A) preconstruction SY males (2007-2008); (B) postconstruction SY males (2009-2011); (C) preconstruction ASY males; and (D) postconstruction ASY males. Filled circles = observed mass; solid line $=$ predicted line of best fit from model including the additive effects of date of capture and distance to turbine (dotted lines $=95 \%$ confidence intervals).

Reproductive success among male Greater Prairie-Chickens is highly skewed and is best explained by rates of display and aggressive behavior, and not by body mass or other morphometrics (Nooker and Sandercock 2008, McNew et al. 2011). Thus, small changes in male body mass may be unlikely to affect male dominance hierarchies or individual reproductive success.

Age, sex, and habitat quality can influence body mass or condition of birds, with subsequent effects on reproductive success (Weimerskirch 1992, Marra et al. 1998). Male lek attendance was high for both age-classes of Greater PrairieChickens, with $>90 \%$ of all territorial males attending each day (Nooker and Sandercock 2008). We observed a midseason peak in body mass of SY males, followed by an approximately $8-10 \%$ decrease from early April to mid-May (Figure 5A, 5B). A decrease in mass over the second half of the breeding season may represent a departure from optimal body mass, potentially putting SY males at risk during inclement environmental conditions or other physiological stressors late in the breeding season (Rogers 1987). Unexpectedly, Hagen et al. (2005) found that survival rates of SY males (0.60) were consistently high compared to those of ASY males (0.44) in Lesser Prairie-Chickens and that higher survival of SY males is a general pattern among male grouse. Alternatively, loss of body mass by SY males could be adaptive if maintaining body mass is physiologically costly or affects flight performance and predator avoidance (Brodin 2006, Ratikainen and Wright 2013).

\section{Conclusions}

The USFWS recommends that new wind energy development should be sited outside of an $8-\mathrm{km}$ buffer zone around active leks in prairie grouse habitat (Manville 2004). Our results show that both male and female Greater Prairie-Chickens have negative behavioral responses to wind energy development within $8 \mathrm{~km}$ of turbines (Winder et al. 2014b, present study). Lek persistence was also affected by habitat and number of males. Further work is needed to test for lag effects and to explore how wind energy development may be affecting long-term population-level processes.

\section{ACKNOWLEDGMENTS}

We thank the many field technicians who helped with data collection for our project. We especially thank S. Richards, D. 


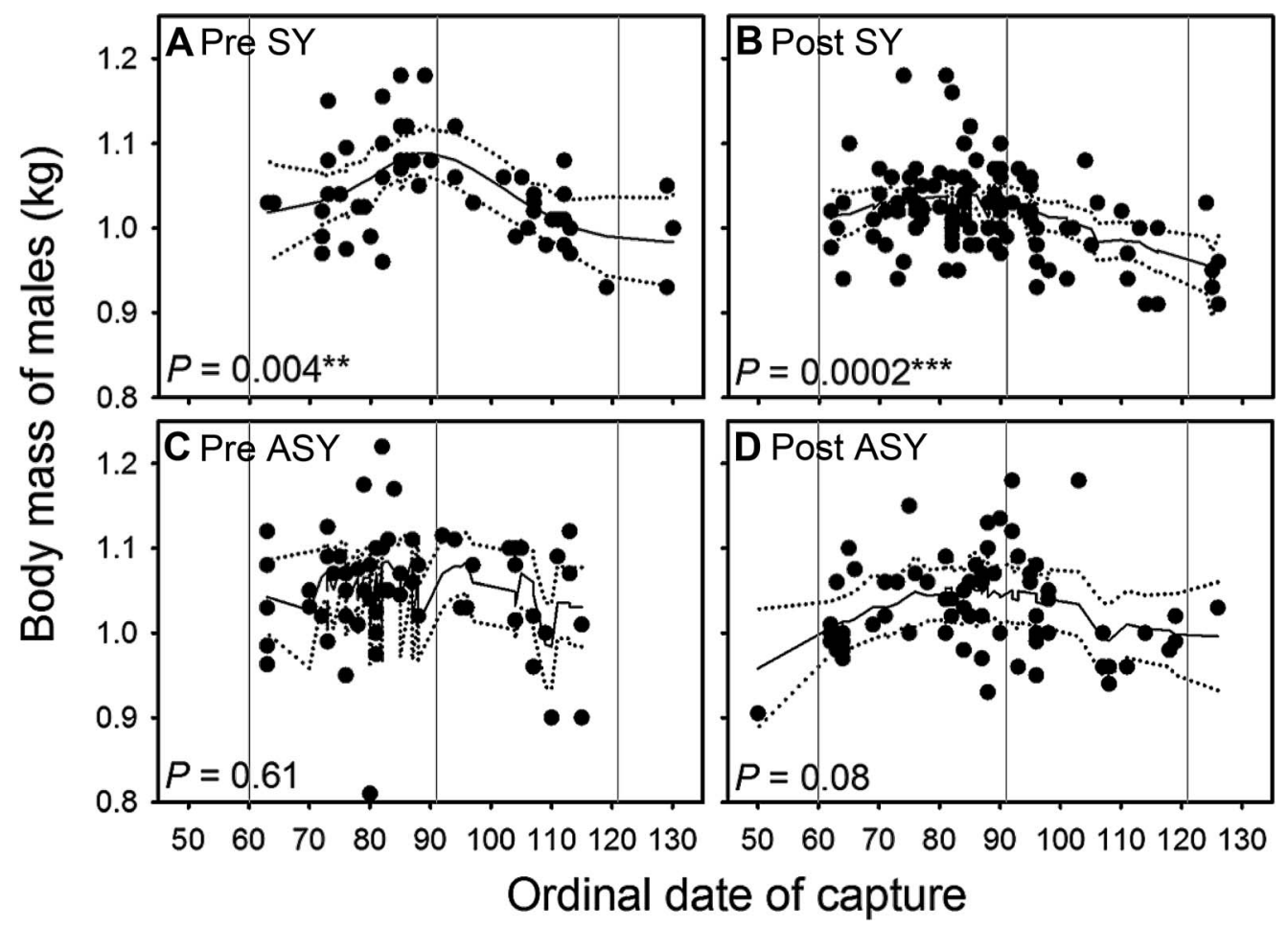

FIGURE 6. Generalized additive model for the effects of date of capture on body mass of male Greater Prairie-Chickens at a wind energy development site in north-central Kansas, USA: (A) preconstruction SY males (2007-2008); (B) postconstruction SY males (2009-2011); (C) preconstruction ASY males; and (D) postconstruction ASY males. Filled circles = body mass; solid line = predicted line of best fit from model including the additive effects of date of capture and distance to turbine (vertical gray lines: March 1, April 1 , and May 1 at days 60,91, and 121; dotted lines $=95 \%$ confidence intervals).

Weaver, L. Perry, and other private landowners in Kansas for allowing us access to their properties.

Funding statement: Research funding and equipment were provided by a consortium of federal and state wildlife agencies, conservation groups, and wind energy partners under the National Wind Coordinating Collaborative, including the Department of Energy; National Renewable Energies Laboratory; U.S. Fish and Wildlife Service; Kansas Department of Wildlife, Parks, and Tourism; Kansas Cooperative Fish and Wildlife Research Unit; National Fish and Wildlife Foundation; Kansas and Oklahoma chapters of The Nature Conservancy; BP Alternative Energy; FPL Energy; Horizon Wind Energy; and Iberdrola Renewables.

Ethics statement: All capture, marking, and tracking activities were performed under institutional animal care and use protocols and state wildlife research permits.

\section{LITERATURE CITED}

Allison, T., D. Anderson, E. Arness, M. Azeko, G. T. Bancroft, K. Boydston, R. Braud, S. Darling, A. Delach, S. Enfield, G. Hueckel, L. Lawrence, et al. (2010). Wind Turbine Guidelines Advisory Committee, Secretary of the Interior USFWS Report. Arnold, T. W., and R. M. Zink (2011). Collision mortality has no discernible effect on population trends of North American birds. PLOS One 6:e24708.
Aspbury, A. S., and R. M. Gibson (2004). Long-range visibility of Greater Sage-Grouse leks: A GIS-based analysis. Animal Behaviour 67:1127-1132.

Augustine, J. K., and B. K. Sandercock (2011). Demography of female Greater Prairie-Chickens in unfragmented grasslands in Kansas. Avian Conservation and Ecology 6:art2.

Bachman, G., and F. Widemo (1999). Relationships between body composition, body size and alternative reproductive tactics in a lekking sandpiper, the Ruff (Philomachus pugnax). Functional Ecology 13:411-416.

Blickley, J. L., D. Blackwood, and G. L. Patricelli (2012a). Experimental evidence for the effects of chronic anthropogenic noise on abundance of Greater Sage-Grouse at leks. Conservation Biology 26:461-471.

Blickley, J. L., K. R. Word, A. H. Krakauer, J. L. Phillips, S. N. Sells, C. C. Taff, J. C. Wingfield, and G. L. Patricelli (2012b). Experimental chronic noise is related to elevated fecal corticosteroid metabolites in lekking male Greater SageGrouse (Centrocercus urophasianus). PLOS One 7:e50462.

Bradbury, J. W., R. M. Gibson, C. E. McCarthy, and S. L. Vehrencamp (1989). Dispersion of displaying male sage grouse: II. The role of female dispersion. Behavioral Ecology and Sociobiology 24:15-24.

Brodin, A. (2006). Theoretical models of adaptive energy management in small wintering birds. Philosophical Transactions of the Royal Society of London, Series B 362:18571871. 
Connelly, J. W., M. A. Schroeder, A. R. Sands, and C. E. Braun (2000). Guidelines to manage Sage-Grouse populations and their habitats. Wildlife Society Bulletin 28:967-985.

Dinkins, J. B., M. R. Conover, C. P. Kirol, J. L. Beck, and S. N. Frey (2014). Greater Sage-Grouse (Centrocercus urophasianus) select habitat based on avian predators, landscape composition, and anthropogenic features. The Condor: Ornithological Applications 116:629-642.

Doherty, K. E., D. E. Naugle, and J. S. Evans (2010). Currency for offsetting energy development impacts: Horse-trading SageGrouse on the open market. PLOS One 5:e10339.

Doherty, K. E., D. E. Naugle, B. L. Walker, and M. G. Jon (2008). Greater Sage-Grouse winter habitat selection and energy development. Journal of Wildlife Management 72:187-195.

Drewitt, A. L., and R. H. W. Langston (2006). Assessing the impacts of wind farms on birds. Ibis 148:29-42.

Drummer, T. D., G. C. Coracelll, and S. J. Sjogren (2011). Sharptailed Grouse lek attendance and fidelity in upper Michigan. Journal of Wildlife Management 75:311-318.

Garton, E. O., J. W. Connelly, C. A. Hagen, J. S. Horne, A. Moser, and M. A. Schroeder (2011). Greater Sage-Grouse population dynamics and probability of persistence. Studies in Avian Biology 38:293-381.

Geary, M., A. H. Fielding, and S. J. Marsden (2012). The anatomy of population change in a Black Grouse population 19922008. Oecologia 168:73-81.

Gibson, R. M. (1996a). A re-evaluation of hotspot settlement in lekking grouse. Animal Behavior 52:993-1005.

Gibson, R. M. (1996b). Female choice in Sage Grouse: The roles of attraction and active comparison. Behavioral Ecology and Sociobiology 39:55-59.

Gibson, D., E. J. Blomberg, M. T. Atamian, and J. S. Sedinger (2014). Lek fidelity and movement among leks by male Greater Sage-Grouse Centrocercus urophasianus: A capturemark-recapture approach. Ibis 156:729-740.

Gregory, A. J., and J. L. Beck (2014). Spatial heterogeneity in response of male Greater Sage-Grouse lek attendance to energy development. PLOS One 9:e97132.

Gregory, A. J., L. B. McNew, T. J. Prebyl, S. M. Wisely, and B. K. Sandercock (2011). A multi-scale hierarchical modeling approach to mapping Greater Prairie-Chicken (Tympanuchus cupido) lekking habitat across central Kansas. Studies in Avian Biology 39:21-32.

Hagen, C. A., J. C. Pitman, T. M. Loughin, B. K. Sandercock, R. J. Robel, and R. D. Applegate (2011). Impacts of anthropogenic features on habitat use by Lesser Prairie-Chickens. Studies in Avian Biology 39:63-75.

Hagen, C. A., J. C. Pitman, B. K. Sandercock, R. J. Robel, and R. D. Applegate (2005). Age-specific variation in apparent survival rates of male Lesser Prairie-Chickens. The Condor 107:78-86.

Hale, A. M., E. S. Hatchett, J. A. Meyer, and V. J. Bennett (2014). No evidence of displacement due to wind turbines in breeding grassland songbirds. The Condor: Ornithological Applications 116:472-482.

Harju, S. M., M. R. Dzialak, R. C. Taylor, L. D. Hayden-Wing, and J. B. Winstead (2010). Thresholds and time lags in effects of energy development on Greater Sage-Grouse populations. Journal of Wildlife Management 74:437-448.

Henderson, F. R., F. W. Brooks, R. E. Wood, and R. B. Dahlgren (1967). Sexing of prairie grouse by crown feather patterning. Journal of Wildlife Management 31:764-769.
Hess, J. E., and J. L. Beck (2012). Disturbance factors influencing Greater Sage-Grouse lek abandonment in north-central Wyoming. Journal of Wildlife Management 76:1625-1634.

Höglund, J., and R. Alatalo (1995). Leks. Princeton University Press, Princeton, NJ, USA.

Johnson, G. D., and S. E. Stephens (2011). Wind power and biofuels: A green dilemma for wildlife conservation. In Energy Development and Wildlife Conservation in Western North America (D. E. Naugle, Editor). Island Press, Washington, DC, USA. pp. 131-155.

Johnson, J. A., M. A. Schroeder, and L. A. Robb (2011). Greater Prairie-Chicken (Tympanuchus cupido), In The Birds of North America 36 (A. Poole, Editor). Birds of North America, Ithaca, NY, USA.

Kunz, T. H., E. B. Arnett, B. M. Cooper, W. P. Erickson, R. P. Larkin, T. Mabee, M. L. Morrison, M. D. Strickland, and J. M. Szewczak (2007). Assessing impacts of wind-energy development on nocturnally active birds and bats: A guidance document. Journal of Wildlife Management 71:2449-2486.

Kuvlesky, W. P., L. A. Brennan, M. L. Morrison, K. K. Boydston, B. M. Ballard, and F. C. Bryant (2007). Wind energy development and wildlife conservation: Challenges and opportunities. Journal of Wildlife Management 71:2487-2498.

Lima, S. L. (1986). Predation risk and unpredictable feeding conditions: Determinants of body mass in birds. Ecology 67: 377-385.

Lindén, M., L. Gustafsson, and T. Pärt (1992). Selection on fledging mass in the Collared Flycatcher and the Great Tit. Ecology 73:336-343.

Lyon, A. G., and S. H. Anderson (2003). Potential gas development impacts on Sage-Grouse nest initiation and movement. Wildlife Society Bulletin 31:486-491.

Mainguy, J., J. Betty, G. Gauthier, and J. Giroux (2002). Are body condition and reproductive effort of laying Greater Snow Geese affected by the spring hunt? The Condor 104:156161.

Manville, A. M. (2004). Prairie grouse leks and wind turbines: U.S. Fish and Wildlife Service justification for a 5-mile buffer from leks; additional grassland songbird recommendations. United States Fish and Wildlife Service Division of Migratory Bird Management, Arlington, Virginia, USA. pp. $1-17$.

Marra, P. P., K. A. Hobson, and R. T. Holmes (1998). Linking winter and summer events in a migratory bird by using stablecarbon isotopes. Science 282:1884-1886.

McNew, L. B., A. J. Gregory, and B. K. Sandercock (2013). Spatial heterogeneity in habitat selection: Nest site selection by Greater Prairie-Chickens. Journal of Wildlife Management 77: 791-801.

McNew, L. B., A. J. Gregory, S. M. Wisely, and B. K. Sandercock (2011). Reproductive biology of a southern population of Greater Prairie-Chickens. Studies in Avian Biology 39:209221.

McNew, L. B., L. M. Hunt, A. J. Gregory, S. M. Wisely, and B. K. Sandercock (2014). Effects of wind energy development on nesting ecology of Greater Prairie-Chickens in fragmented grasslands. Conservation Biology 28:1089-1099.

Merrill, M. D., K. A. Chapman, K. A. Poiani, and B. Winter (1999). Land-use patterns surrounding Greater Prairie-Chicken leks in northwestern Minnesota. Journal of Wildlife Management 63: 189-198. 
Niemuth, N. D. (2003). Identifying landscapes for Greater PrairieChicken translocation using habitat models and GIS: A case study. Wildlife Society Bulletin 31:145-155.

Nooker, J. K., and B. K. Sandercock (2008). Correlates and consequences of male mating success in lek-mating Greater Prairie-Chickens (Tympanuchus cupido). Behavioral Ecology and Sociobiology 62:1377-1388.

Obermeyer, B., R. Manes, J. Kiesecker, J. Fargione, and K. Sochi (2011). Development by design: mitigating wind development's impacts on wildlife in Kansas. PLOS One 6:e26698.

Pearce-Higgins, J. W., L. Stephen, A. Douse, and R. H. W. Langston (2012). Greater impacts of wind farms on bird populations during construction than subsequent operation: Results of a multi-site and multi-species analysis. Journal of Applied Ecology 49:386-394.

Peig, J., and A. J. Green (2009). New perspectives for estimating body condition from mass/length data: The scaled mass index as an alternative method. Oikos 118:1883-1891.

Pitman, J. C., C. A. Hagan, B. E. Jamison, R. J. Robel, T. M. Loughlin, and R. D. Applegate (2005). Location and success of Lesser Prairie-Chicken nests in relation to vegetation and human disturbance. Journal of Wildlife Management 69: 1259-1269.

Pruett, C. L., M. A. Patten, and D. H. Wolfe (2009). Avoidance behavior by prairie grouse: Implications for wind energy development. Conservation Biology 23:1253-1259.

Racine, J. S., and Z. Nie (2012). Categorical regression splines. R package crs version 0.15-23. http://CRAN.R-project.org/ package $=$ crs

Ratikainen, I. I., and J. Wright (2013). Adaptive management of body mass by Siberian Jays. Animal Behaviour 85:427-434.

Rogers, C. M. (1987). Predation risk and fasting capacity: Do wintering birds maintain optimal body mass? Ecology 4: 1051-1061.

Sandercock, B. K., E. B. Nilsen, H. Brøseth, and H. C. Pedersen (2011). Is hunting mortality additive or compensatory to natural mortality? Effects of experimental harvest on the survival and cause-specific mortality of Willow Ptarmigan. Journal of Animal Ecology 80:244-258.

Schaub, M., and J.-D. Lebreton (2004). Testing the additive versus the compensatory hypothesis of mortality from ring recovery data using a random effects model. Animal Biodiversity and Conservation 27:73-85.

Schroeder, M. A., and C. E. Braun (1992). Greater Prairie-Chicken attendance at leks and stability of leks in Colorado. Wilson Bulletin 104:273-284.

Schroeder, M. A., and G. C. White (1993). Dispersion of Greater Prairie-Chicken nests in relation to lek location: Evaluation of the hot-spot hypothesis of lek evolution. Behavioral Ecology 4:266-270.

Smallwood, K. S., and C. Thelander (2008). Bird mortality in the Altamont Pass Wind Resource Area, California. Journal of Wildlife Management 72:215-223.

Sovacool, B. K. (2009). Contextualizing avian mortality: A preliminary appraisal of bird and bat fatalities from wind, fossil-fuel, and nuclear electricity. Energy Policy 37:22412248.

Svedarsky, W. D., R. L. Westemeier, R. J. Robel, S. Gough, and J. E. Toepher (2000). Status and management of the Greater Prairie-Chicken Tympanuchus cupido pinnatus in North America. Wildlife Biology 6:277-284.

U.S. Department of Energy (2008). 20\% wind by 2030: Increasing wind energy's contribution to U.S. electricity supply. U.S. Department of Energy, Washington, DC, USA.

Walker, B. L., D. E. Naugle, and K. E. Doherty (2007). Greater SageGrouse population response to energy development and habitat loss. Journal of Wildlife Management 71:2644-2654.

Weimerskirch, H. (1992). Reproductive effort in long-lived birds: Age-specific patterns of condition, reproduction and survival in the Wandering Albatross. Oikos 64:464-473.

Winder, V. L., L. B. McNew, A. J. Gregory, L. M. Hunt, S. M. Wisely, and B. K. Sandercock (2014a). Effects of wind energy development on the survival of Greater Prairie-Chickens. Journal of Applied Ecology 51:395-405.

Winder, V. L., L. B. McNew, A. J. Gregory, L. M. Hunt, S. M. Wisely, and B. K. Sandercock (2014b). Space use by female Greater Prairie-Chickens in response to wind energy development. Ecosphere 5:art3.

Wood, S. N. (2011). Fast stable restricted maximum likelihood and marginal likelihood estimation of semiparametric generalized linear models. Journal of the Royal Statistical Society of London, Series B 73:3-36. 


\section{APPENDIX}

TABLE 2. Peak counts of male Greater Prairie-Chickens at 23 lek sites in the Smoky Hills ecoregion of north-central Kansas, USA, 2007-2012. Counts are weighted means adjusted for survey technique, including flush counts and trap counts.

\begin{tabular}{|c|c|c|c|c|c|c|c|c|c|c|c|c|}
\hline \multirow[b]{3}{*}{ Lek } & \multirow[b]{3}{*}{ Habitat } & \multirow[b]{3}{*}{$\begin{array}{l}\text { Distance to } \\
\text { turbine } \\
(\mathrm{km})\end{array}$} & \multicolumn{4}{|c|}{ Preconstruction } & \multicolumn{6}{|c|}{ Postconstruction } \\
\hline & & & \multicolumn{2}{|c|}{2007} & \multicolumn{2}{|c|}{2008} & \multicolumn{2}{|c|}{2009} & \multicolumn{2}{|c|}{2010} & \multicolumn{2}{|c|}{2011} \\
\hline & & & $\begin{array}{l}\text { Maximum } \\
\text { number } \\
\text { of males }\end{array}$ & $\begin{array}{l}\text { Number } \\
\text { of } \\
\text { surveys }\end{array}$ & $\begin{array}{c}\text { Maximum } \\
\text { number } \\
\text { of males }\end{array}$ & $\begin{array}{l}\text { Number } \\
\text { of } \\
\text { surveys }\end{array}$ & $\begin{array}{l}\text { Maximum } \\
\text { number } \\
\text { of males }\end{array}$ & $\begin{array}{c}\text { Number } \\
\text { of } \\
\text { surveys }\end{array}$ & $\begin{array}{l}\text { Maximum } \\
\text { number } \\
\text { of males }\end{array}$ & $\begin{array}{c}\text { Number } \\
\text { of } \\
\text { surveys }\end{array}$ & $\begin{array}{c}\text { Maximum } \\
\text { number } \\
\text { of males }\end{array}$ & $\begin{array}{c}\text { Number } \\
\text { of } \\
\text { surveys }\end{array}$ \\
\hline $\mathrm{H}$ & Grass & 0.04 & 6 & 6 & 8 & 5 & 7 & 7 & 3 & 4 & 0 & 3 \\
\hline$E$ & Crop & 0.11 & 13 & 7 & 9 & 10 & 3 & 6 & 0 & 3 & 1 & 3 \\
\hline G & Grass & 0.11 & - & - & - & - & - & - & - & - & 7 & 21 \\
\hline $\mathrm{L}$ & Grass & 0.12 & - & - & - & - & 13 & 14 & 16 & 20 & 14 & 20 \\
\hline $\mathrm{F}$ & Crop & 0.22 & - & - & - & - & 22 & 28 & 10 & 16 & 1 & 3 \\
\hline K & Grass & 0.68 & - & - & 9 & 20 & 14 & 17 & 10 & 16 & 12 & 15 \\
\hline I & Crop & 2.01 & 17 & 15 & 10 & 12 & 4 & 5 & 1 & 3 & 1 & 3 \\
\hline D & Crop & 2.46 & - & - & - & - & 19 & 3 & 25 & 2 & 14 & 3 \\
\hline $\mathrm{J}$ & Crop & 2.57 & - & - & - & - & - & - & - & - & 12 & 1 \\
\hline C & Grass & 3.16 & - & - & 10 & 17 & 0 & 1 & 3 & 4 & 0 & 2 \\
\hline M & Grass & 3.18 & 4 & 3 & 6 & 6 & 8 & 7 & 9 & 8 & 7 & 10 \\
\hline$N$ & Grass & 3.95 & 16 & 7 & 24 & 18 & 26 & 26 & 15 & 21 & 22 & 37 \\
\hline $\mathrm{O}$ & Grass & 4.16 & - & - & - & - & 15 & 9 & 8 & 7 & 6 & 12 \\
\hline$P$ & Grass & 4.84 & - & - & - & - & 15 & 10 & 13 & 18 & 11 & 30 \\
\hline B & Grass & 6.06 & - & - & 14 & 18 & 13 & 16 & 15 & 11 & 10 & 31 \\
\hline A & Grass & 6.39 & - & - & 12 & 10 & 17 & 29 & 7 & 13 & 8 & 11 \\
\hline Q & Grass & 6.57 & - & - & 25 & 19 & 17 & 19 & 15 & 15 & 14 & 33 \\
\hline$S$ & Crop & 15.92 & 12 & 7 & 3 & 2 & 0 & 1 & - & - & 8 & 1 \\
\hline $\mathrm{T}$ & Crop & 16.64 & 21 & 6 & 26 & 17 & 17 & 11 & 12 & 9 & 21 & 16 \\
\hline U & Crop & 18.18 & 14 & 8 & 13 & 8 & 10 & 10 & 7 & 13 & 8 & 9 \\
\hline $\mathrm{R}$ & Grass & 22.04 & 15 & 11 & 13 & 6 & 24 & 2 & - & - & - & - \\
\hline V & Crop & 27.07 & 12 & 10 & 16 & 9 & 18 & 16 & 29 & 8 & 32 & 8 \\
\hline W & Grass & 27.64 & 18 & 3 & - & - & 10 & 2 & 10 & 2 & 4 & 2 \\
\hline
\end{tabular}

Notes: Habitat: grass = native grassland, crop = agricultural field. Dash indicates that no sampling was conducted. Leks with $\geq 4$ males present were considered active, and leks with $<4$ males present were considered inactive. Leks $A-D, F, J-L$, and $O-Q$ were discovered after the start of the study. Gaps in monitoring at leks J, S, and W were caused by restricted access to private lands. 